\title{
Evaluation of a coagulation assay determining the activity state of factor VII in plasma
}

Citation for published version (APA):

van Deijk, W. A., van Dam-Mieras, M. C. E., Muller, A. D., \& Hemker, H. C. (1983). Evaluation of a coagulation assay determining the activity state of factor VII in plasma. Haemostasis, 13(3), 192-197. https://doi.org/10.1159/000214726

Document status and date:

Published: 01/01/1983

DOI:

10.1159/000214726

Document Version:

Other version

\section{Please check the document version of this publication:}

- A submitted manuscript is the version of the article upon submission and before peer-review. There can be important differences between the submitted version and the official published version of record.

People interested in the research are advised to contact the author for the final version of the publication, or visit the DOI to the publisher's website.

- The final author version and the galley proof are versions of the publication after peer review.

- The final published version features the final layout of the paper including the volume, issue and page numbers.

Link to publication

\footnotetext{
General rights rights.

- You may freely distribute the URL identifying the publication in the public portal. please follow below link for the End User Agreement:

www.umlib.nl/taverne-license

Take down policy

If you believe that this document breaches copyright please contact us at:

repository@maastrichtuniversity.nl

providing details and we will investigate your claim.
}

Copyright and moral rights for the publications made accessible in the public portal are retained by the authors and/or other copyright owners and it is a condition of accessing publications that users recognise and abide by the legal requirements associated with these

- Users may download and print one copy of any publication from the public portal for the purpose of private study or research.

- You may not further distribute the material or use it for any profit-making activity or commercial gain

If the publication is distributed under the terms of Article $25 \mathrm{fa}$ of the Dutch Copyright Act, indicated by the "Taverne" license above, 


\title{
Evaluation of a Coagulation Assay Determining the Activity State of Factor VII in Plasma
}

\author{
W.A. van Deijk ${ }^{\mathrm{a}}$, M.C.E. van Dam-Mieras ${ }^{\mathrm{b}}$, A.D. Muller ${ }^{\mathrm{b}}$, H.C. Hemker ${ }^{\mathrm{b}}$ \\ a Department of Internal Medicine, University Hospital Annadal, and bepartment of Biochemistry, \\ University of Limburg, Maastricht, The Netherlands
}

Key Words. Factor VIIa · Factor VII · Factor VII-deficient plasma · Cold-promoted activation · Factor VIIa assay

Abstract. A coagulation assay is described that allows the measurement of the degree of activation of factor VII in circulating blood. The test is based on the use of both bovine and human brain thromboplastin, together with an artificial factor VII-deficient plasma. The latter can be prepared on a relatively large scale which makes it possible to measure factor VII activation in large series of patients.

The determination of factor VII activation during incubation at $4{ }^{\circ} \mathrm{C}$ of plasma of women using oral contraceptives shows that the test described adequately measures factor VII activation. Differences in the time course of factor VII activation during this incubation in glass and plastic containers are found and implicate that rigorous standardization of blood sampling and test conditions is necessary. A possible mechanism that causes this critical dependence upon the test conditions is discussed.

\section{Introduction}

In the preliminary phase of an epidemiological investigation of the activation of coagulation enzymes in the circulating blood of cancer patients we critically assessed the factor VII activation test described by Hemker et al. [6]. The test system described allows the measurement of the degree of activation of factor VII in plasma and is based on the use of both bovine and human brain thromboplastin, together with an artificial factor VIIdeficient reagent. The latter can be prepared on a relatively large scale which makes it pos- sible to measure factor VII activation in a large series of patients. This may be of importance because of the possible epidemiologic use of this estimation [2,9].

The usefulness of the test was assessed by the measurement of factor VII activation during incubation at $4{ }^{\circ} \mathrm{C}$ of pooled plasma of women using oral contraceptive agents (OCAs) [4]. Because differences in the time course of activation of factor VII in plasma during incubation in the cold in glass and plastic containers have been reported in the literature $[4,5,12]$ we also investigated this aspect. 
It will be shown that the test system described adequately measures factor VII activation and that, because of the influence of the incubation conditions upon the degree of factor VII activation, rigorous standardization of the blood sampling and test procedures is highly necessary.

\section{Materials and Methods}

Factor VII-Deficient Reagent. An artificial factor VII-deficient reagent was prepared by a modification of the method of Lechner and Deutsch [6]. The artificial reagent contained: $64 \%$ human factor X, $72 \%$ bovine factor V, $74 \%$ human factor II and $2.25 \mathrm{~g} / \mathrm{l}$ fibrinogen. The results obtained with this reagent showed a perfect correlation with those obtained with congenitally factor VII-deficient plasma [6]. The factor VII concentration of the reagent was $1.68 \%$, determined as described earlier [6].

Thromboplastins. Human and bovine thromboplastins were prepared by a modification of the method of Owren and Aas [11].

Buffer. Veronal/acetate $(0.15 M, \mathrm{pH} 7.4)$.

Sampling Procedure. Blood was obtained by venipuncture after as short a period of stasis as possible and was collected in plastic tubes containing sodium citrate $2 \mathrm{H}_{2} \mathrm{O}$ (final concentration $10 \mathrm{mM}$ ). The first few milliliters of blood were discarded. Plasma was prepared by centrifugation of blood for $10 \mathrm{~min}$ at $3,000 \mathrm{~g}$ and the supernatant for $30 \mathrm{~min}$ at $12,000 \mathrm{~g}$ to bring the platelets down. During blood sampling and plasma preparation procedures only plastic materials were used. Platelet-free plasma was pooled and stored in $1-\mathrm{ml}$ portions at $-20^{\circ} \mathrm{C}$ for $24 \mathrm{~h}$ prior to testing.

Incubation at $4^{\circ} \mathrm{C}$. Immediately after thawing, plasma samples were kept at $4{ }^{\circ} \mathrm{C}$ in plastic or glass tubes. After 0, 1, 2, 4, 24, and $48 \mathrm{~h}$, samples were taken, diluted in buffer and screened for factor VII activation.

Determination of Factor VII Activation. Diluted plasma sample $(0.1 \mathrm{ml})$, factor VII-deficient reagent $(0.1 \mathrm{ml})$ and human or bovine thromboplastin $(0.1 \mathrm{ml})$ were incubated during $30 \mathrm{~s}$ in a glass tube at $37^{\circ} \mathrm{C}$. The coagulation was initiated by the addition of $0.1 \mathrm{ml} \mathrm{CaCl} 2(33 \mathrm{~mm})$ and the coagulation time recorded. All determinations were carried out in du- plicate. The degree of factor VII activation in the test plasma was determined by the ratio of plasma factor VII level determined with bovine thromboplastin over that of plasma factor VII level determined with human thromboplastin as has been suggested previously [7].

Reference Tables. Coagulation times obtained when dilutions of pooled normal human plasma are used as a source of factor VII in a factor VII-deficient medium and tested with either human or bovine thromboplastin were used to construct the reference curves (table I). From these curves reference tables can be derived which makes it possible to determine the factor VII concentration in test plasma in a welldefined range, set by the standard concentrations used to construct the reference tables and even slightly beyond [6].

\section{Results}

In figure 1 the results of the experiments in which plasma from women using OCAs was incubated at $4{ }^{\circ} \mathrm{C}$ under different experi-

Table I. Coagulation times obtained with normal human plasma incubated in glass at $37^{\circ} \mathrm{C}$ with human or bovine thromboplastin (TP) in a factor VII-deficient reagent

\begin{tabular}{lll}
\hline \multirow{2}{*}{$\begin{array}{l}\text { Plasma } \\
\text { concentration } \\
\% \mathrm{v} / \mathrm{v}\end{array}$} & \multicolumn{2}{l}{ Coagulation times } \\
\cline { 2 - 3 } & human TP & bovine TP \\
\hline 20 & 21.8 & 46.3 \\
10 & 26.6 & 54.0 \\
5 & 32.0 & 64.8 \\
2.5 & 38.0 & 73.3 \\
1.67 & 41.7 & 80.3 \\
1.25 & 45.3 & 87.8 \\
1.00 & 48.5 & 86.1 \\
0.50 & 57.7 & 90.5 \\
- & 71.0 & 96.6 \\
\hline
\end{tabular}

SD 1.0\%. Minimal time: with human TP $18.8 \mathrm{~s}$; with bovine TP $34.6 \mathrm{~s}$. 
mental conditions are shown. As can be seen in this figure, the amount of factor VII measured with the test system using human thromboplastin changes appreciably less during the incubation at $4{ }^{\circ} \mathrm{C}$ than the apparent amount of factor VII measured with the test using bovine thromboplastin does. It can further be concluded that, although the time course of factor VII activation during incubation in glass and plastic containers is different, the ultimate stage of factor VII activation is the same in both materials. Furthermore, the curves obtained with different sample dilutions are approximately parallel. As the samples containing relatively high plasma concentrations (5 or $10 \%$ ) produce extremely short coagulation times which fall beyond the validity range of the reference tables [6], coagulation times instead of factor VII levels had to be used on the ordinates in figure 1. In test samples that contain a lower amount of plasma the factor VII concentration can be determined in the usual way. In the figures 2 and 3 the apparent increase in factor VII concentration in plasma of women using OCAs during incubation at $4{ }^{\circ} \mathrm{C}$ in glass as determined with human and bovine thromboplastin respectively is shown. In the figures 4 and 5 the same experiment is depicted for the incubation in plastic. As would be expected from earlier observations, the apparent increase in factor VII activation during incubation in the cold was very pronounced when assayed with bovine thromboplastin and much less evident when assayed with human thromboplastin [7]. As will be discussed below, the stage of activation of factor VII in plasma can best be expressed by the use of the ratio (fig. 6, 7):

Factor VII estimated with bovine thromboplastin Factor VII estimated with human thromboplastin

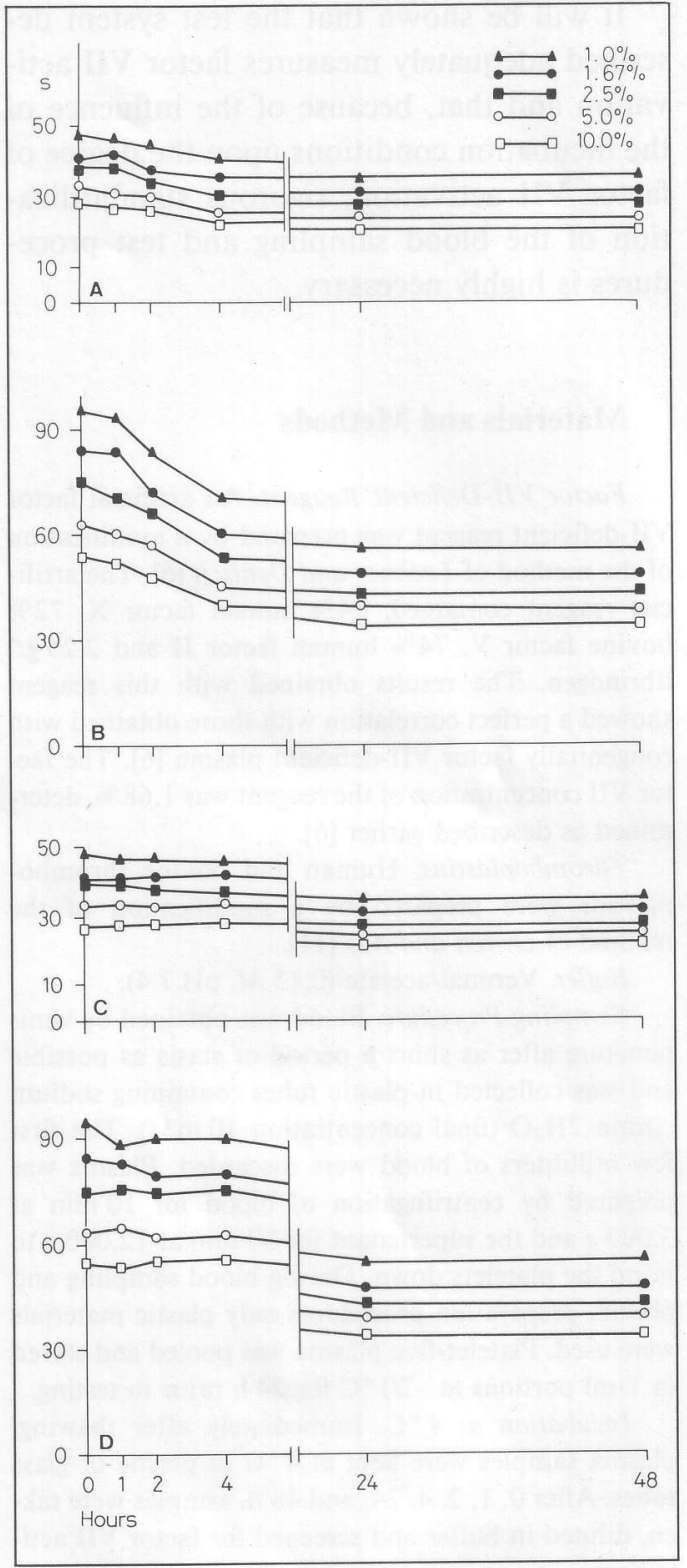

Fig. 1. Shortening of the one-stage test for factor VII in several plasma dilutions during incubation in the cold in plasma of women using OCAs. In A and $\mathbf{B}$ incubation was done in glass, and in $\mathbf{D}$ and $\mathbf{C}$ in plastic. In $\mathbf{A}$ and $\mathbf{C}$ human thromboplastin was used in the test mixture, while in $\mathbf{B}$ and $\mathbf{D}$ bovine thromboplastin was used. 

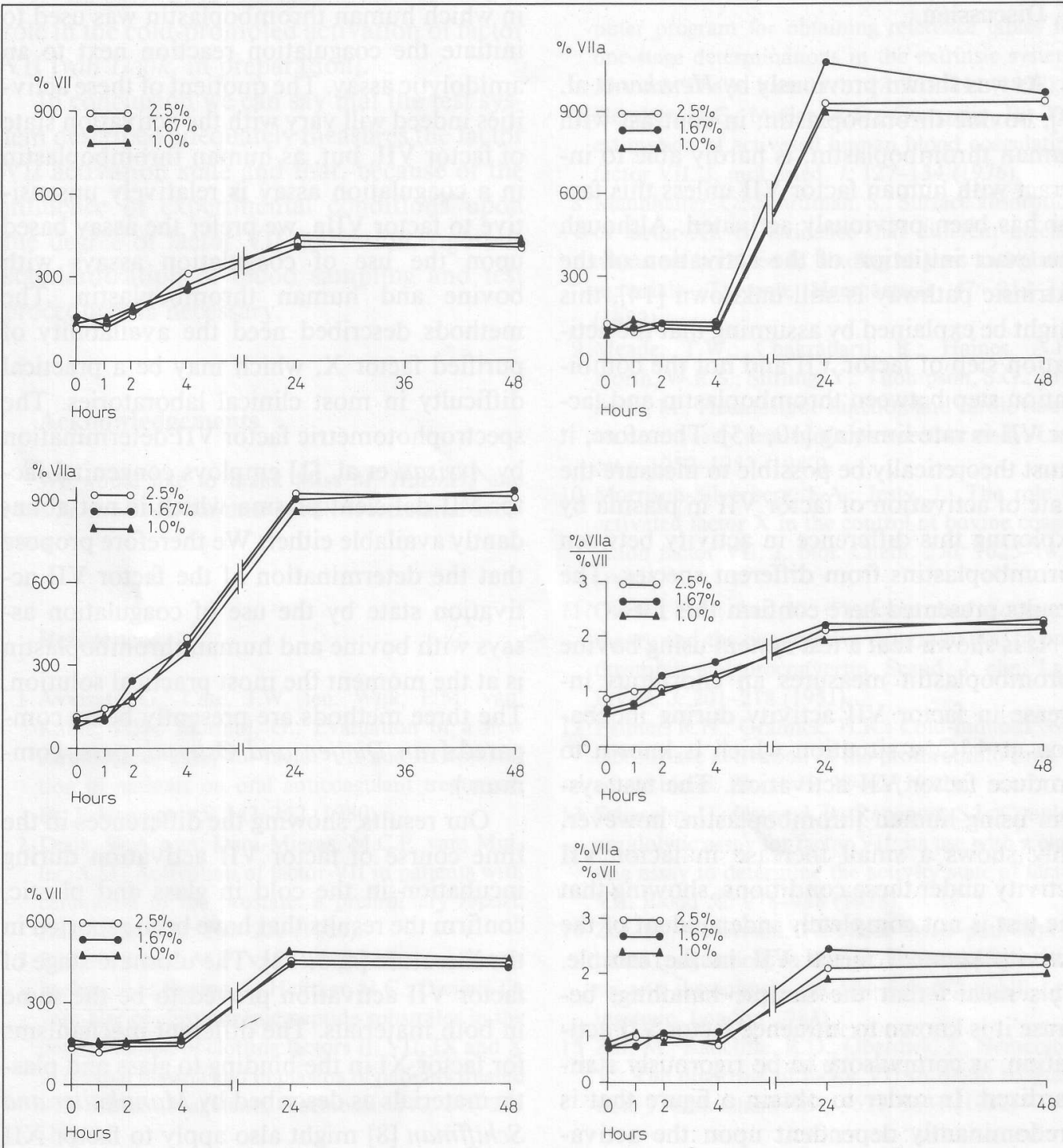

Fig. 2. Activation of factor VII in the cold during incubation of plasma in glass, measured with human brain thromboplastin in several plasma dilutions.

Fig. 3. Activation of factor VII in the cold during incubation of plasma in glass, measured with bovine brain thromboplastin in several plasma dilutions.

Fig. 4. Activation of factor VII in the cold during incubation of plasma in plastic, measured with human thromboplastin in several plasma dilutions.
Fig. 5. Activation of factor VII in the cold during incubation of plasma in plastic, measured with bovine thromboplastin in several plasma dilutions.

Fig. 6. Factor VIIa/factor VII ratio during incubation of plasma in glass, measured in several plasma dilutions.

Fig. 7. Factor VIIa/factor VII ratio during incubation of plasma in plastic, measured in several plasma dilutions. 


\section{Discussion}

As was shown previously by Hemker et al. [7], bovine thromboplastin, in contrast with human thromboplastin, is hardly able to interact with human factor VII unless this factor has been previously activated. Although the exact initiation of the activation of the extrinsic pathway is still unknown [14], this might be explained by assuming that the activation step of factor VII and not the combination step between thromboplastin and factor VII is rate limiting $[10,15]$. Therefore, it must theoretically be possible to measure the state of activation of factor VII in plasma by exploring this difference in activity between thromboplastins from different species. The results presented here confirm this idea.

It is shown that a test system using bovine thromboplastin measures an enormous increase in factor VII activity during incubation at $4{ }^{\circ} \mathrm{C}$, a situation which is known to produce factor VII activation. The test system using human thromboplastin, however, only shows a small increase in factor VII activity under these conditions, showing that the test is not completely independent of the activity state of factor VII in the sample. This means that the sample handling, because it is known to influence factor VII activation, is compulsory to be rigorously standardized. In order to obtain a figure that is predominantly dependent upon the activation state of factor VII rather than upon the absolute amount of this factor present we propose to use the quotient of the activities obtained with bovine and human thromboplastin respectively.

Recently a new coupled amidolytic assay for factor VII has been described [3, 13]. The authors could determine the activation state of factor VII by the use of a coagulation assay in which human thromboplastin was used to initiate the coagulation reaction next to an amidolytic assay. The quotient of these activities indeed will vary with the activation state of factor VII, but, as human thromboplastin in a coagulation assay is relatively unsensitive to factor VIIa, we prefer the assay based upon the use of coagulation assays with bovine and human thromboplastin. The methods described need the availability of purified factor X, which may be a practical difficulty in most clinical laboratories. The spectrophotometric factor VII determination by Avvisati et al. [1] employs congenital factor VII-deficient plasma which is not abundantly available either. We therefore propose that the determination of the factor VII activation state by the use of coagulation assays with bovine and human thromboplastin is at the moment the most practical solution. The three methods are presently being compared [van Dieijen and Østerud, pers. commun.].

Our results, showing the differences in the time course of factor VII activation during incubation in the cold in glass and plastic, confirm the results that have been reported in the literature $[4,5,12]$. The ultimate stage of factor VII activation proved to be the same in both materials. The different mechanisms for factor XI in the binding to glass and plastic materials as described by Mannhalter and Schiffman [8] might also apply to factor XII and kallikrein, leading to their slower activation in plastic compared to glass. As these factors are known to play an important role in the cold-promoted activation of factor VII $[5,12]$, it is tempting to assume that similar mechanisms might play a role in the slower activation of factor VII in plastic compared to glass. Recent experiments show that besides factor XII, factor II might also play a 
role in the cold-promoted activation of factor VII [van Deijk, in preparation].

In conclusion we can say that the test system described adequately measures the factor VII activation state and that, because of the influence of experimental conditions upon the degree of factor VII activation, rigorous standardization of blood sampling and test procedures is necessary.

\section{Acknowledgements}

We would like to thank Miss M. Haemers and Miss M. Molenaar for their excellent secretarial assistance.

\section{References}

1 Avvisati, G.; Cate, J.W. ten; Wijk, E.M. van; Kahlé, L.H.; Mariani, G.: Evaluation of a new chromogenic assay for factor VII and its application in patients on oral anticoagulant treatment. Br. J. Haemat. 45: 343-352 (1980).

2 Deijk, W.A. van; Dam-Mieras, M.C.E. van; Muller, A.D.: Activation of factor VII in patients with carcinoma of the prostate: a preliminary report. Haemostasis 13: 198-200 (1983).

3 Dieijen-Visser, M.P. van; Wersch, J. van; Brombacher, P.J.; Rosing, J.; Hemker, H.C.; Dieijen, G. van: Use of chromogenic peptide substrates in the determination of clotting factors II, VII, IX and X in normal plasma and in plasma of patients treated with oral anticoagulants. Haemostasis 12: 241-255 (1982).

4 Gjønnaes, H.: Cold promoted activation of factor VII. 1. Evidence for the existence of an activator. Thromb. Diath. haemorrh. 28: 155-168 (1972).

5 Gordon, E.M.; Ratnoff, O.D.; Jones, P.K.: The role of augmented Hageman factor (factor XII) titers in the cold-promoted activation of factor VII and spontaneous shortening of the prothrombin time in women using oral contraceptives. J. Lab. clin. Med. 99: 363-369 (1982).

6 Hemker, H.C.; Swart, A.C.W.; Alink, A.M.J.: Artificial reagents for factor VII and factor $\mathrm{X}$, a com- puter program for obtaining reference tables for one-stage determinations in the extrinsic system. Thromb. Diath. haemorrh. 27: 205-211 (1972).

7 Hemker, H.C.; Muller, A.D.; Gonggrijp, R.: The estimation of activated human blood coagulation factor VII. J. mol. Med. 1: 127-134 (1976).

8 Mannhalter, C.; Schiffman, S.: Surface absorption of factor XI. II. Evidence that different mechanisms are involved in binding to glass and plastic materials. Thromb. Haemostasis 47: 214-217 (1982).

9 Meade, T.W.; Chakrabarti, R.; Haines, A.P.; North, W.R.S.; Stirling, Y.; Thompson, S.G.; Brozovic, M.: Haemostatic function and cardiovascular death: early results of a prospective study. Lancet $i$ : 1050-1053 (1980).

10 Morrison-Silverberg, S.A.; Jesty, J.: The role of activated factor $\mathrm{X}$ in the control of bovine coagulation factor VII. J. biol. Chem. 256: 1625-1630 (1981).

11 Owren, P.A.; Aas, K.: The control of dicumarol theory and the quantitative determination of prothrombin and proconvertin. Scand. J. clin. Lab. Invest. 3: 201-218 (1951).

12 Palmer, R.N.; Gralnick, H.R.: Cold-induced contact surface activation of the prothrombin time in whole blood. Blood 59: 38-42 (1982).

13 Seligsohn, U.; Østerud, B.; Rapaport, S.I.: Coupled amidolytic assay for factor VII: its use with a clotting assay to determine the activity state of factor VII. Blood 52: 978-988 (1978).

14 Zur, M.; Nemerson, Y.: Tissue factor pathways of blood coagulation; in Bloom, Thomas, Haemostasis and thrombosis, pp. 124-139 (Churchill Livingstone, London 1981).

15 Zur, M.; Radcliffe, R.D.; Oberdick, J.; Nemerson, Y.: The dual role of factor VII in blood coagulation. J. biol. Chem. 257: 5623-5631 (1982).
W.A. van Deijk,
Department of Internal Medicine,
University Hospital Annadal,
NL-6201 BX Maastricht (The Netherlands) 